\title{
HILFER AND HADAMARD COUPLED VOLTERRA FRACTIONAL INTEGRO-DIFFERENTIAL SYSTEMS WITH RANDOM EFFECTS
}

\author{
SaÏd AbBas, Ravi P. Agarwal, Mouffak Benchohra \\ AND Boualem ATTOU SLIMANi
}

Abstract. This paper deals with some existence results for two classes of coupled systems of Hilfer and Hilfer-Hadamard random fractional integro-differential equations. The main tool used to carry out our results is Itoh's random fixed point theorem.

Mathematics subject classification (2010): 26A33.

Keywords and phrases: Fractional integro-differential equation, Riemann-Liouville integral of fractional order, Hadamard integral of fractional order, Hilfer fractional derivative, Hadamard fractional derivative, coupled system, random solution, existence, fixed point.

\section{REFERENCES}

[1] S. Abbas, W. Albarakati And M. Benchohra, Successive approximations for functional evolution equations and inclusions, J. Nonlinear Funct. Anal., Vol. 2017 (2017), Article ID 39, pp. 1-13.

[2] S. Abbas, M. Benchohra, J. Graef And J. Henderson, Implicit Fractional Differential and Integral Equations; Existence and Stability, De Gruyter, Berlin, 2018.

[3] S. Abbas, M. Benchohra and J. Henderson, Partial Hadamard-Stieltjes fractional integral equations in Banach spaces, Manuscript for a chapter in the Banas, et al. Springer book, Advances in Nonlinear Analysis via the Concept of Measure of Noncompactness, Chapter 9, (2017), 375-391.

[4] S. Abbas, M. Benchohra, J. Henderson And J. E. LAZREG, Measure of noncompactness and impulsive Hadamard fractional implicit differential equations in Banach spaces, Math. Eng. Science Aerospace 8 (3) (2017), 1-19.

[5] S. Abbas, M. Benchohra, J. E. Lazreg and Y. Zhou, A Survey on Hadamard and Hilfer fractional differential equations: Analysis and Stability, Chaos, Solitons Fractals 102 (2017), 47-71.

[6] S. AbBas, M. Benchohra And G. M. N'GuÉRÉKATA, Topics in Fractional Differential Equations, Springer, New York, 2012.

[7] S. Abbas, M. Benchohra and G. M. N'GuÉrékata, Advanced Fractional Differential and Integral Equations, Nova Science Publishers, New York, 2015.

[8] B. Ahmad, A. Alsaedi, S. K. Ntouyas, J. Tariboon, Hadamard-type Fractional Differential Equations, Inclusions and Inequalities, Springer, Cham, 2017.

[9] B. AHMAD, R. LUCA, Existence of solutions for a sequential fractional integro-differential system with coupled integral boundary conditions, Chaos Solitons Fractals 104 (2017), 378-388.

[10] A. Als Aedi, S. Aljoudi, B. Ahmad, Existence of solutions for Riemann-Liouville type coupled systems of fractional integro-differential equations and boundary conditions, Electron. J. Differential Equations 2016, paper no. 211, 14 pp.

[11] S. Aljoudi, B. Ahmad, J. J. Nieto, A. Als Aedi, A coupled system of Hadamard type sequential fractional differential equations with coupled strip conditions, Chaos Solitons Fractals 91 (2016), 3946.

[12] A. T. Bharucha-ReID, Random Integral Equations, Academic Press, New York, 1972.

[13] J. M. Cushing, Forced asymptotically periodic solutions of predator-prey systems with or without hereditary effects, Siam J. Appl. Math. 30 (1976), 665-674.

[14] B. C. DHAGE, Existence theory for first order functional random integrodifferential inclusions, Nonlinear Stud. 24 (2017), 309-328. 
[15] B. C. Dhage, R. G. Metkar, Approximating monotonically the unique random solutions of second order periodic random boundary value problems, Comm. Appl. Nonlinear Anal. 22 (2015), 34-44.

[16] J. Diblik, E. Schmeidel, M. Ruzickova, Asymptotically periodic solutions of Volterra system of difference equations, Comput. Math. Appl. 59 (2010), 2854-2867.

[17] J. DiBLIK, E. SCHMEIDEL, M. RuZICKOVA, Existence of asymptotically periodic solutions of system of Volterra difference equations, J. Differ. Equ. Appl. 15 (2009), 1165-1177.

[18] K. M. FurATI AND M. D. KASSIM, Non-existence of global solutions for a differential equation involving Hilfer fractional derivative, Electron. J. Differential Equations 2013, no. 235, 10 pp.

[19] K. M. FURATI, M. D. KASSIM, AND N. E. TATAR, Existence and uniqueness for a problem involving Hilfer fractional derivative, Comput. Math. Appl. 64 (2012), 1616-1626.

[20] A. Granas And J. Dugundj, Fixed Point Theory, Springer-Verlag, New York, 2003.

[21] X. Z. HE, K. Gopalsamy, Dynamics of Lotka-Volterra mutualism in changing environments, Dynam. Systems Appl. 1 (1994), 173-185.

[22] R. Hilfer, Applications of Fractional Calculus in Physics, World Scientific, Singapore, 2000.

[23] S. IтоH, Random fixed point theorems with applications to random differential equations in Banach spaces, J. Math. Anal. Appl. 67 (1979), 261-273.

[24] V. K. JiRs A, H. HAKEN, Field theory of electromagnetic brain activity, Phys. Rev. Lett. 77 (1996), 960-963.

[25] H. F. HuO, W. T. LI, Oscillation criteria for certain two-dimensional differential systems, Int. J. Appl. Math. 6 (2001), 253-261.

[26] R. KAMOCKI AND C. OBCZŃNSKI, On fractional Cauchy-type problems containing Hilfer's derivative, Electron. J. Qual. Theory Differ. Equ., 2016, no. 50, 1-12.

[27] A. A. Kilbas, Hadamard-type fractional calculus, J. Korean Math. Soc. 38 (6) (2001), 1191-1204.

[28] A. A. Kilbas, H. M. SRivastava And J. J. Trujillo, Theory and Applications of Fractional Differential Equations, Elsevier Science B. V., Amsterdam, 2006.

[29] G. S. Ladde and V. Lakshmikantham, Random Differential Inequalities, Academic Press, New York, 1980.

[30] D. T. J. Liley, P. J. Cadusch, J. J. Wright, A continuum theory of electro-cortical activity, Neurocomputing 26-27 (1999), 795-800.

[31] V. Lupulescu, D. O'Regan, G. UR RAhman, Ghaus, Existence results for random fractional differential equations, Opuscula Math. 34 (2014), 813-825.

[32] M. D. QAssim, K. M. Furati, And N.-E. TATAR, On a differential equation involving HilferHadamard fractional derivative, Abstr. Appl. Anal., vol. 2012, Article ID 391062, 17 pages, 2012.

[33] M. D. QASSIM AND N.-E. TATAR, Well-posedness and stability for a differential problem with HilferHadamard fractional derivative, Abstr. Appl. Anal., vol. 2013, Article ID 605029, 12 pages, 2013.

[34] Y. N. RAFFOUL, Classification of positive solutions of nonlinear systems of Volterra integral equations, Ann. Funct. Anal. 2 (2011), 34-41.

[35] S. G. Samko, A. A. Kilbas And O. I. Marichev, Fractional Integrals and Derivatives. Theory and Applications, Gordon and Breach, Amsterdam, 1987, Engl. Trans. from the Russian.

[36] V. E. TARASov, Fractional Dynamics: Application of Fractional Calculus to Dynamics of Particles, Fields and Media, Springer, Heidelberg; Higher Education Press, Beijing, 2010.

[37] Ž. Tomovski, R. Hilfer And H. M. SRIVASTAVA, Fractional and operational calculus with generalized fractional derivative operators and Mittag-Leffler type functions, Integral Transforms Spec. Funct. 21 (11) (2010), 797-814.

[38] C. P. Tsokos And W. J. PAdGett, Random Integral Equations with Applications to Life Sciences and Engineering, Academic Press, New York, 1974.

[39] J.-R. WANG, AND Y. ZHANG, Nonlocal initial value problems for differential equations with Hilfer fractional derivative, Appl. Math. Comput. 266 (2015), 850-859.

[40] H. R. Wilson, J. D. CowAn, Excitatory and inhibitory interactions in localized populations of model neurons, Biophys. J. 12 (1972), 1-24.

[41] H. R. Wilson, J. D. Cowan, A mathematical theory of the functional dynamics of cortical and thalamic nervous tissue, Kybernetik 13 (1973), 55-80.

[42] Y. ZHou, Basic Theory of Fractional Differential Equations, World Scientific, Singapore, 2014. 